\title{
DISTRIBUTION CHANNEL INTENSITY AMONG TABLE WATER PRODUCERS IN NIGERIA
}

\author{
Joseph Edewor Agbadudu, Simon Ayo Adekunle* \\ Department of Business Administration, Faculty of Management Sciences, University of \\ Benin, Benin City, Nigeria \\ edewor.agbadudu@gmail.com \\ simon.adekunle@uniben.edu
}

\begin{abstract}
Planning for and making reasonable decisions regarding reaching the target market with an organization's product is a critical task on the part of management, which involves a careful evaluation and selection of its channel structure and intensity. This study therefore examines distribution channel intensity among table water producers in Edo State, Nigeria. The focus of the study is to ascertain the variables that significantly predict distribution intensity among the firms in the table water industry in Edo State. The study seeks to proffer answer to fundamental question of why brands within a single category of a given consumer good differ significantly in their distribution intensity. Using a survey research design, the data used for this study were obtained by taking a sample of 110 table water firms within the three senatorial districts in the State. The data obtained were presented and analyzed using different statistical tools such as mean and multiple regression through Statistical Packages for Social Sciences (SPSS) version 22 software. Findings revealed that manufacturers' target focus, manufacturers' support program, brand quality and level of firm's technological advancement were significant predictors of distribution channel intensity among the industrial players in table water industry in the State. Based on the findings, the study recommended that table water firms within the State can secure a competitive edge over their fellow counterpart in the industry by designing an optimal distribution intensity that will meet up their marketing objectives. It is also recommended that the adoption of modern technology in form of online sales is an efficient way of sales and distribution which could be used to enhance their distribution techniques if there is a need to cut down on middle men due to increased cost. The study concluded that optimal distribution intensity could be achieved not by mere imitation of competitors but through a careful definition and analyses of target focus, support programs, quality of their brand as well as the level of technological advancement of the firms.
\end{abstract}

Keywords: channel, distribution, producers, support program, target focus, water.

JEL Classification: M3, M31, M310.

\section{Introduction}

Marketing managers of modern day organizations are faced with variety of challenges one of which is the decision about the distribution of the organization's product (Hamid and Seydeh, 2014). Planning for and making reasonable decisions regarding reaching the target market with an organization's product is a critical task on the part of management, which involves a careful evaluation and selection of its channel structure and intensity. Getting the right product produced, with the right market price, and backed up with an effective promotional strategy are quite necessary for sustainable competitive advantage. However, these do not

\footnotetext{
* Corresponding Author: Simon Ayo Adekunle
} 
guarantee maximum customer satisfaction without these products being delivered optimally and timely to the customer at the right location (Jobber, 2009). Thus, the central role of distribution within the marketing mix cannot be overemphasized since the inability to get the product to the desired destination will result in loss of customer retention. Given this as the case, the competitive dynamics in emerging and existing markets has moved organizations to direct their focus on the management of their distribution channels as a means of competitive edge (Cônsoli and Neves, 2008).

Within a broad range of consumer goods, producers vary significantly in their approach to distribution of their brands through intermediaries. In other words, for manufacturers of consumer goods within the same product line, the level of intensity used by a producer for his brand differs significantly from one producer to another, irrespective of the fact that the same channel structure may be adopted. While several studies have elaborated on distribution decision of established domestic and multinational companies, as well as the dynamics and causes of multichannel conflicts (Gaski, 1996; Li, 2003), there is only very limited knowledge on what factors determine the level and differences in distribution intensity among producers, in distributing their products. In other words, why are brands within a single category of a given consumer good differ significantly in their distribution intensity? This portrays a significant research gap in the literature indicating the little attention which has been given to channel intensity in academic research. To fill this gap, this study centers on empirically testing a set of antecedents based on previous studies that predicts the degree of distribution channel intensity among selected manufacturers of a product line of consumer goods intensively distributing their brands in a geographical area. Empirical studies in existing literature proposed variables such as target focus, support programs, and coordination effort of manufacturers; as well as the quality and sales volume of the brand as likely determinants (Frazier and Lassar, 1996). The essence of this paper is to empirically ascertain the extent to which the aforementioned variables influence the level of distribution channel intensity among producers of table water in Edo State.

\section{Review of Related Literature}

Water is a universal liquid of life that is needed by all living organisms. Naturally, water is available everywhere under the ground. However, not all is good for drinking in their natural forms as it contains some contaminants that are harmful to the body system. In Nigeria, table water production and consumption has gained much attention. According to Alika, Ikuemonisan and Kalu (2016), "table water consumption is the daily requirements for both the rich and the poor in Nigeria". It is in line with this that table water firms are established in different parts of the country to produce drinkable water for meeting the needs of the people.

\subsection{Concept of Distribution Channel Intensity}

Different scholars have defined the concepts of distribution and distribution channel intensity in various ways. Jobber (2009) opined that all products whether they are consumer goods, industrial goods or services require a channel of distribution. According to Webster (1991), distribution is defined "as the process through which goods produced are moved from the manufacturers to the consumers". Being an element of the marketing mix which is represented as place in most marketing literature, it has been clarified that the central function of distribution management is having the product placed in the hands of the desired target consumers at the right location and in a timely fashion (Roosta and Abdul, 2009). Agbonifoh, Ogwo, Nnolim and Nkamnebe (2007) opined that distribution planning involves activities such as "production planning and materials procurement, inventory management and the related problems of receiving, in-bound transportation, and order processing, packaging, in-plant warehousing, shipping, out-bound transportation, field warehousing, and retail-outlet planning, operations and control". Rosenbloom (2007) described distribution 
channel as the external contractual organization that management operates to achieve its distribution objectives. According to Richard (1976) cited in Ilesanmi (2011), channel of distribution is "a combination of middlemen that a company uses to move its products to the ultimate purchaser". Irrespective of the definitional approach, channels of distribution always incorporate both the producer and the final customer for the product in its present form as well as any middlemen such as retailers and wholesalers (llesanmi, 2011).

Distribution channel intensity has been simply defined by Stem, El-Ansary and Coughlan (1996) as the number of intermediaries used by a manufacturer within its trade area. Frazier and Lassar (1996) defined it as "the extent to which a manufacturer relied on numerous retailers in each trade area to carry its brand". Ideal distribution intensity would make a brand available widely enough to satisfy target customers' needs, because oversaturation increases marketing costs without providing benefits (McCarthy and Perreault, 1984). In other words, the use of too few intermediaries can limit a brand's level of exposure in the marketplace. However, using too many intermediaries can be detrimental to the brand's image and its competitive position. Distribution intensity is relatively low when manufacturers are highly selective in their choice of associated retailers and put strict limits on the number of retailers allowed to carry their brands in each trade area, nevertheless a high level of distribution intensity is sought for a majority of consumer non-durable goods (Frazier and Lassar, 1996).

\subsection{Determinants of Distribution Channel Intensity}

Few studies have identified different factors determining distribution intensity among producers in an industry (Jain, 1993; Li, 2003; Mallen, 1996; Webster, 1991). In this study, six (6) antecedents of distribution channel intensity namely: manufacturers target focus, manufacturers support programs, manufacturers coordination effort, brand quality, brand sales volume and technological advancement are discussed.

Manufacturer Target Focus: This refers to the degree to which a producer focuses attention on a specific or broad section of the entire market. Some producers may choose to concentrate on a wider spectrum of the market with its brand, and as such will be required to face the challenge of reaching various individual and class of customers with different buying habit and characteristic for the brand (Frazier and Lassar, 1996). According to Levy and Barton (1992), "an intensive distribution approach is likely necessary in such cases to ensure adequate availability of the brand".

Hypothesis One: Manufacturer's target focus does not significantly influence distribution channel intensity.

Manufacturers Support Program: This refers to incentive offered by producers to assist associated intermediaries carrying their brand. This may include promotional allowance, credit grants, accounting support and dealer hotline (Frazier and Lassar, 1996). There are marked variation among producers in their use and dependence on support programs (Hunt and Nevin, 1974; Lusch, 1976). Provision of support program by manufacturers in their channel is usually aimed at encouraging channel members interest in their brand and assist them in their distribution effort. Thus intermediaries in the channel mechanism can be well motivated by these incentives (Gaski and Nevin, 1985; Shipley, 1984).

The availability of support incentives to intermediaries or retail outlets tends to reduce the task inherent in distribution. Challenges relating to carriage, selling and brand servicing will be minimized thus resulting in decreased cost and risk possibility for retailers. Therefore, increase in support programs by producers are likely to result in the attraction of more intermediaries in the channel mechanism thereby increasing the channel intensity. Nevertheless, a limitation on this is the possibility of producers cost of rendering support 
programs being far higher than the marginal benefit obtained from the activities of attracted retailers (Frazier and Lassar, 1996).

Hypothesis Two: Manufacturers support program does not significantly influence distribution channel intensity.

Manufacturers Coordination Efforts: This shows the degree of producers' trial in influencing the actions and decisions of their middlemen (Skinner and Guiltinan, 1985). Reasonable amount of time and energy are usually expended but most producers in coordinating the relationship and activities of their market intermediaries while for some, the cost associated in doing this has constituted a hindrance (Stem, et al., 1996). The desire to closely coordinate channel relationship on the parts of most producers, will require them to reduce the number of intermediaries used in a given territory (Rosenbloom, 2007).

Hypothesis Three: Manufacturers coordination efforts do not significantly influence distribution channel intensity.

Brand Quality: A brand's positioning on quality reflects the extent to which a manufacturer attempts to convey to consumers that the brand has superior ability to meet their expectation with respect to performance (Kotler and Armstrong, 2004; Zeithaml, 1988). It would be highly productive for producers whose brand are placed on the lower end of quality to depend on large number of middlemen in each trade territory for effective promotion of the brand given reasonable pricing policy. Conversely, for producers with positive remarks on their brands with respect to quality, they are likely to exert more diligence and care in selecting prospective intermediaries since the brand's reputation could be affected by the kind of retailer selected (Lusch, 1976).

Hypothesis Four: Brand quality does not significantly influence distribution channel intensity.

Brand Sales Volume: Previous studies in the literature tend to examine the relationship of the sales volume of a brand with its distribution intensity (Frazier and Lassar, 1996; Stem, et al., 1996). Sales volume of a brand defines the rate of the brand turnover within a specified time period which in most cases is subjected to monetary measurement. Sales volume of a brand is proposed to be reciprocally related to its distribution intensity (Frazier and Lassar, 1996). The implication of this is that brands that are frequently remarkable as generating higher sales to the perception of both its producers and consumers are likely to capture the patronage of higher number of retail outlets and intermediaries thus increasing the channel intensity level. Invariably higher distribution intensity for the brand can possibly result in higher volume of sales (Stem, et al., 1996).

Hypothesis Five: Brand sales volume does not significantly influence distribution channel intensity.

Technological Advancement: Advancement of modern technology has significantly influenced virtually all aspect of human endeavor. One of such relevant area is on the aspect of marketing. Modern day manufacturers have considered the internet a great help to facilitating their operation particularly in the aspect of product display and online shopping. The internet which is a clear indication of technological advancement improves product commercialization, as well as facilitates information circulation on product availability (Jain, 1993). Thus, the full exploitation of modern technology which is well pronounced in the widespread use of the internet by manufacturers may likely rather reduce their tendency to use higher number of marketing intermediaries or distribution intensity since the difficulty encountered in the coordination of these middle men could be even out through maximum use of technological provisions in the environment while still achieving the same objective of product display, awareness, and customer patronage. 
Hypothesis Six: Technological advancement does not significantly influence distribution channel intensity.

\section{Methodology}

This study adopted the survey approach. The study entailed a cross-sectional design of table water producers operating in Edo State. The study population covered all table water producers operating within Edo State. The population of table water producers in the State based on government records as at the time of this study was one hundred and fifty eight.

Table 1: Population of registered table water producers in Edo State

\begin{tabular}{|c|l|c|}
\hline $\mathbf{S} / \mathbf{N}$ & Senatorial Districts in Edo State & Number of Producers \\
\hline 1 & Edo Central & 45 \\
\hline 2 & Edo North & 35 \\
\hline 3 & Edo South & 78 \\
\hline Total Population & 158 \\
\hline
\end{tabular}

Source: Researchers' field work (2016)

The total sample size for the study was statistically determined by Taro Yamane's (1967) formula given as: $\quad \mathrm{n}_{\mathrm{T}}=\frac{\mathbb{N}}{1+N(\Theta)^{2}}$

Where: $\mathrm{N}=$ Aggregate population of all registered table water factories in Edo state.

$\mathrm{n}_{\mathrm{T}}=$ Total sample of registered table water producers in Edo state.

$\mathrm{e}=$ Level of significance.

$1=$ Constant

Through substitution of values into the above formula,

$$
\mathrm{n}_{\mathrm{T}}=\frac{N}{1+N(e)^{2}}=\frac{158}{1+158(0.05)^{2}}=113.2616 \cong 113 \text { (Approximately) }
$$

The generated sample size derived through the Yamane's formula is one hundred and thirteen. The researchers considered this number to be a sizable representation of the entire population under study. The study adopted a primary source of data collection. This involves administering questionnaires to respondents who are majorly table water producers or their representatives in the firms. Using a convenience sampling technique, the one hundred and thirteen copies of the questionnaire were distributed to table water firms.

The questionnaire was structured into different parts namely the introductory letter, and the classification sections divided into Sections A and B. Basically, the letter helps to enhance the response rate of the questionnaire by assuring the respondents that the information provided by them shall be used strictly for academic purpose. Section A elicits information on company profile such as length of establishment and senatorial location of firms. Section B addresses the other variables such as manufacturers' target focus, manufacturers' support programs, coordination effort, brand sales volume, brand quality, and technological advancement.

The model for the study is specified as:

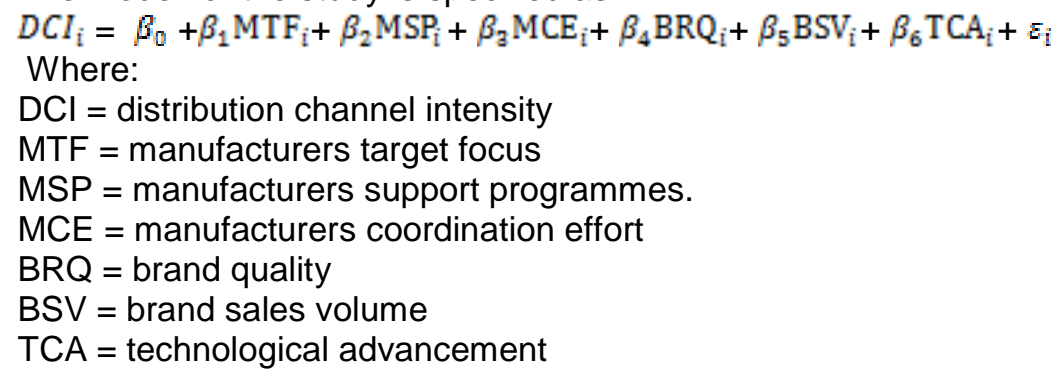


$\varepsilon=$ Stochastic error term

$\mathrm{i}=$ Cross sectional data; $\beta_{0}=$ Constant $\beta_{1}=\beta_{6}=$ Coefficients of the independent variables Based on the study objectives, ordinary least square (OLS) technique was used to estimate the relationship between distribution channel intensity and the independent variables (manufacturers' target focus, support programs, coordination effort, brand quality, brand sales volume, and technological advancement). The data obtained were presented and analyzed using different statistical tools such as mean and multiple regression through Statistical Packages for Social Sciences (SPSS) version 22 software.

\section{Results and Discussions}

\subsection{Description of Company Profile}

One hundred and thirteen (113) copies of the questionnaire were distributed to table water producers or their official representatives in Edo State. Of this number, 110 copies of the questionnaire were completed, retrieved and found usable. This represents a response rate of 97 percent. The response rate was satisfactory because the copies of questionnaires that were properly filled were the only ones used by the researchers. Table 2 presents the company profile of the selected table water firms.

Table 2: Company Profile

\begin{tabular}{|c|c|c|c|c|}
\hline $\mathbf{S} / \mathbf{N}$ & Variables & Categories & Frequency & Percentage (\%) \\
\hline \multirow{6}{*}{1} & \multirow{6}{*}{$\begin{array}{l}\text { Length of firm } \\
\text { establishment }\end{array}$} & Below 5 years & 41 & 37.27 \\
\hline & & $6-11$ years & 34 & 30.91 \\
\hline & & $12-17$ years & 19 & 17.27 \\
\hline & & $18-23$ years & 2 & 1.82 \\
\hline & & 24 years and above & 14 & 12.73 \\
\hline & & Total & 110 & 100 \\
\hline \multirow{4}{*}{2} & \multirow{4}{*}{$\begin{array}{l}\text { Senatorial } \\
\text { location of firms }\end{array}$} & Edo Central & 29 & 36.36 \\
\hline & & Edo North & 24 & 21.82 \\
\hline & & Edo South & 57 & 51.82 \\
\hline & & Total & 110 & 100 \\
\hline
\end{tabular}

Source: Researchers' field work (2016)

Length of Firm Establishment: Table 2 shows that $37.27 \%$ of the table water firms examined in this study were established in less than 5years. 34 of them representing $30.91 \%$ fall within $6-11$ years of establishment, 19 of the firms representing $17.27 \%$ were established between $12-17 y e a r s . ~ O n l y ~ 14.55 \%$ of the firms have operated for 18years and above.

Senatorial Location of Firm: Each state in Nigeria is divided into three senatorial districts with different Local Government Areas (LGAs). Edo State is divided into Edo Central (Esan Central, Esan North-East, Esan South-East, Esan West and Igueben [LGAs]), Edo North (Akoko-Edo, Etsako Central, Etsako East, Etsako West, Owan East and Owan West [LGAs]) and Edo South (Egor, Ikpoba-Okha, Oredo, Orhionmwon, Ovia North West, Ovia North West and Uhunmwonde [LGAs]). Table 2 showed that Edo South accounts for 57 representing $51.82 \%$ of the total responding firms. This is followed by Edo Central which accounts for (29) firms representing $26.36 \%$ and lastly Edo North (24) representing $21.82 \%$ of the total responding firms. Thus, this shows that Edo South accounted for the highest number of responding firms in Edo State. 


\section{2. $\quad$ Description of Dependent and Independent Variables}

Each item in the variables presented in Table 3 was structured in 5-point Likert scale of 5, 4, 3, 2, 1 for Strongly Agree, Agree, Neutral, Disagree and Strongly Disagree respectively. The weighted mean score was calculated by multiplying the frequency of each point by the weight and later divided by the total number of respondents. The implication of this is that, the higher the mean, the more the level of "agreement" with respect to the variable and vice versa. The results for the variables are shown below:

Table 3: Description of Variables

\begin{tabular}{|c|l|c|}
\hline S/N & \multicolumn{1}{|c|}{ Variables } & Mean Score $(\overline{\boldsymbol{X}})$ \\
\hline \multicolumn{3}{|c|}{ Dependent Variable } \\
\hline 1 & Distribution channel intensity \\
\hline \multicolumn{3}{|c|}{ Independent Variables } \\
\hline 1 & Manufacturer target focus & 4.77 \\
\hline 2 & Manufacturer support program & 4.46 \\
\hline 3 & Manufacturer coordination effort & 4.35 \\
\hline 4 & Brand quality & 4.62 \\
\hline 5 & Brand sales volume & 3.45 \\
\hline 6 & Technological advancement & 3.28 \\
\hline
\end{tabular}

Source: Researchers' field work (2016)

The mean score of 4.77 revealed that majority of the respondents highly agreed with the items used in measuring distribution channel intensity. Similarly, the mean scores of the independent variables shown in Table 3 revealed that majority of the respondents agreed with the items used in measuring them as the values are greater than the mid-point of 3 .

\subsection{Model Estimation and Interpretation}

This section statistically establishes the relationship between distribution channel intensity and the independent variables (target focus, support programs, coordination effort, brand quality, brand sales volume, and technological advancement). The regression results are shown in Tables 4, 5 and 6.

Table 4: Model Summary

\begin{tabular}{|c|c|c|c|c|}
\hline $\mathbf{R}$ & $\mathbf{R}$ Square & Adjusted R Square & Std. Error of the Estimate & Durbin- Watson \\
\hline $0.512^{\mathrm{a}}$ & 0.262 & 0.219 & 0.637 & 2.131 \\
\hline
\end{tabular}

a. Predictors: (Constant), MTF, MSP, MCE, BRQ, BSV, TCA

Source: Researchers' field work (2016)

Table 4 shows that when the independent variables were regressed on distribution channel intensity, a coefficient of determination $\left(R^{2}\right)$ value of 0.262 is obtained. This indicates that the independent variables jointly explained $26.2 \%$ of the variation in the dependent variable. Based on the Durbin-Watson statistics of 2.131, there is no presence of auto-correlation in the model.

Table 5: ANOVA $^{\mathrm{a}}$

\begin{tabular}{|l|c|c|c|c|c|}
\hline Model & Sum of Squares & df & Mean Square & F & Sig. \\
\hline Regression & 14.815 & 6 & 2.469 & \multirow{2}{*}{6.093} & $0.000^{\mathrm{b}}$ \\
\hline Residual & 41.739 & 103 & 0.405 & & \\
\hline Total & 56.555 & 109 & & & \\
\hline
\end{tabular}

a. Dependent Variable: DCI

b. Predictors: (Constant), MTF, MSP, MCE, BRQ, BSV, TCA

Source: Researchers' field work (2016) 
Table 5 shows that the F-statistic of 6.093 is significant at $p<0.05$. This means that there is a statistical significant relationship between the independent variables and the dependent variable as a whole.

Table 6: Coefficients ${ }^{\mathrm{a}}$

\begin{tabular}{|c|c|c|c|c|c|}
\hline \multirow{2}{*}{ Model } & \multicolumn{2}{|c|}{ Unstandardized Coefficients } & \multirow{2}{*}{\begin{tabular}{|c} 
Standardized Coefficients \\
Beta
\end{tabular}} & \multirow{2}{*}{$\mathbf{T}$} & \multirow{2}{*}{ Sig. } \\
\hline & B & Std. Error & & & \\
\hline (Constant) & 10.878 & 0.967 & & 11.246 & 0.000 \\
\hline MTF & 0.89 & 0.044 & 0.193 & 2.025 & 0.045 \\
\hline MSP & 0.138 & 0.048 & 0.255 & 2.855 & 0.005 \\
\hline MCE & 0.012 & 0.020 & 0.050 & 0.582 & 0.562 \\
\hline $\mathrm{BRQ}$ & 0.083 & 0.037 & 0.211 & 2.218 & 0.029 \\
\hline BSV & -0.028 & 0.019 & -0.133 & -1.499 & 0.137 \\
\hline TCA & -0.095 & 0.044 & -0.193 & -2.169 & 0.032 \\
\hline
\end{tabular}

a. Dependent Variable: $\mathrm{DCl}$

Source: Researchers' field work (2016)

Table 6 reveals that MTF, MSP, BRQ and TCA significantly influence $\mathrm{DCl}$ at $\mathrm{p}<0.05$. However, MCE and BSV are not significant at 5\%. The sign of the coefficients of the variables are all positive signs except for BSV and TCA that have negative relationships with DCl.

\subsection{Discussion of Findings}

Firstly, this study found that there is very high distribution channel intensity $(\bar{X}=4.77)$ among table water producers in Edo State. This suggests that table water firms in the State prefer to use larger number of intermediaries in the distribution mechanism of their products. Manufacturers target focus (MTF) of most table water firms in Edo State was shown to be high $(\bar{X}=4.46)$, and also a significant predictor of distribution channel intensity. The result indicated that the target focus of manufacturers is positively related to their distribution intensity. The implication of this is that as table water producers concentrate on a broader spectrum of the market, the more number of intermediaries they use in the channel mechanism, while focusing on a narrow spectrum of the market will invariably result in the use of few retailers in the channel. This finding corroborates the findings of Frazier and Lassar (1996).

Secondly, manufacturers support programs (MSP) was shown to be high $(\overline{\bar{X}}=4.35)$ and constitute another significant predictor of distribution channel intensity. This means that table water firms in the State offer sufficient support incentives to the retailers carrying their brand. The result further showed that manufacturers' support program is the most significant predictor of the distribution channel intensity of table water producers in Edo State. In addition, manufacturers' support program is found to be positively related with distribution channel intensity. Therefore, the channel intensity of these table water firms increases as more support programs are offered to retailers in the channel. While the reduction or complete withdrawal of support incentives by producers may results in loss of retailers in the channel mechanism.

Thirdly, manufacturers' coordination effort (MCE) was found to be insignificant in predicting the variability in distribution channel intensity among table water brands in Edo State. This implies that producers' effort in terms of the time and energy to be expended in influencing the action and decision of their middlemen does not significantly determine the number of retailer used in the channel mechanism. Furthermore, brand quality was found to be high $(\bar{X}=4.45)$ and constitute another significant predictor of distribution channel intensity. This suggests that most table water brands in the State are positioned on the higher end of the 
quality continuum by their manufacturers. Brand quality was also found to have a positive relationship with distribution channel intensity. This implies that the more a table water brand is perceived to be of high quality, the higher the intensity of its channel of distribution by its producers. Brand sales volume was found not to be a significant predictor of distribution channel intensity. This suggests that the volume of table water sales by firms in Edo State does not significantly determine the number of middlemen used in the channel mechanism. Finally, technological advancement was found to be a significant predictor of distribution channel intensity. The analyses revealed that firms in the table water industry in Edo State are technologically advanced particularly in terms of online sale and distribution of their products. Technological advancement was found to have an inverse relationship with the level of distribution channel intensity among table water producers in Edo State. This suggests that table water firms in the state tend to cut down on the use of the number of middlemen in their channel as they advance more towards online marketing of their brands.

\section{Conclusion and Recommendations}

This study was carried out to examine the distribution channel intensity among table water producers within Edo state. The study provided empirical evidence on the reasons behind the differences in distribution intensity among table water producers in the State. Based on the results obtained, it was concluded that the key predictors in distribution channel intensity among producers of table water are the manufacturers' target focus, manufacturers' support programs, brand quality and technological advancement of the given firm in terms of internet marketing and online sale and display.

Based on the analyses and findings from this study, the following recommendations are made:

- Table water firms within the State can secure a competitive edge over their counterparts in the industry by designing an optimal distribution intensity that will meet up their marketing objectives.

- They should ensure that their target focus are appropriately determined before determining the number of retailers to use in other to prevent over saturation of the market with the brand and increase cost over returns due to excessive use of retailers in the channel.

- Adoption of modern technology in form of online sales is an efficient way of sales and distribution which could be used to enhance their distribution techniques if there is a need to cut down on middle men due to increased cost.

- For new firms in the industry, more retail outlet could be attracted to carry their brands through systematic and objective use of support program and incentives

- Finally, the study was restricted to Edo State and further streamlined to table water factories within the State. It is therefore recommended that future studies of this kind should be undertaken in other states of the Federation thereby giving deeper insights into the subject matter.

\section{Acknowledgements}

We acknowledge the contributions of Kenechukwu Nwafor-Nwangwu in administering and retrieving the questionnaires used for this study. The contributions of Frazier and Lassar are sincerely appreciated as their paper on the determinants of distribution intensity provided great insight on the subject matter.

\section{References}

Agbonifoh, B. A., Ogwo, O. E., Nnolim, D.A. and Nkamnebe, A. O. (2007). Marketing in Nigeria: Concepts, Principles And Decisions. Aba: Afritowers Publishers Limited. 
Alika, J. E., Ikuemonisan, A. P. and Kalu, P. N. (2016). Business Enterprises: The UNIBEN Table Water Factory experience. In F.O. McOliver, F.C. Okafor, N. A. Nwagwu and C.E.E. Okojie (Eds), Entrepreneurship Development: The Nigerian Experience. Benin City: Mareh Publishers.

Cônsoli, M. A. and Neves, M. F. (2008). 'A Method for Building New Marketing Channels: The case of "Door-to-Door" in Dairy Products', An International Journal of Marketing, vol. 2, no. 3, pp.174-185.

Frazier, G.L. and Lassar, M. W. (1996). 'Determinants of Distribution Intensity' Journal of Marketing, vol. 60, no. 1, pp. 39-51.

Gaski, J. and Nevin, J. (1985). 'The Differential Effects of Exercised and Unexercised Power Sources in a Marketing Channel', Journal of Marketing Research, No. 22 (May), pp.130-42. Gaski, J. F. (1996). 'Distribution Channels: A Validation Study' International Journal of Physical Distribution and Logistics Management, vol. 26, no. 5, p. 64-93.

Hamid, S. and Seydeh, M. (2014). 'Management of Distribution Channels. Indian Journal of Science Research, vol. 5, no. 3, pp. 452-456.

Hunt, S. and Nevin, J. (1974), 'Power in a Channel of Distribution: Sources and Consequences', Journal of Marketing Research, (May), pp.186-193.

Ilesanmi, O. A. (2011). 'The Significance of Distribution Channel and Product Life Cycle in the Management of an Organization: The Nigerian Experience. Global Journal of Management and Business Research, vol.11, no. 10, pp. 5-16.

Jain, S. (1993). International Marketing Management (4th Edition). California: Wadsworth Publishers.

Jobber, D. (2009). Principles and Practice of Marketing (6th Edition). London: McGraw-Hill Companies.

Kotler, P. and Armstrong, G. (2004). Principles of Marketing (3rd Edition). New Jersey: Prentice Hall.

Levy, M. and Barton A, W. (1992). Retailing Management. Homewood, IL: Richard D, Irwin. $\mathrm{Li}, \mathrm{L}$. (2003). 'Determinants of Export Distribution Intensity in Emerging Markets: The British Experience in China', Asia Pacific Journal of Management, vol. 20, no. 4, pp. 501-516.

Lusch, R. F. (1976), 'Sources of Power: Their Impact on Intrachannel Conflict," Journal of Marketing Research, no. 13 (November), pp. 382-390.

Mallen, B. (1996). 'Marketing Channels and Economic Development: A Literature Overview', International Journal of Physical Distribution and Logistics Management, vol. 26, no. 5, pp. 42-47.

McCarthy, E.J. and Perreault, W. (1984). Basic Marketing. Homewood: Irwin Publishers.

Roosta, A. V. and Abdul, D.A. (2009). Marketing Management. The Study and Compilation Books. Tehran: Human Sciences Publishing Company.

Rosenbloom, B. (2007). 'Multi-Channel Strategy in Business-to-Business Markets: Prospects and Problems', Journal of Industrial Marketing Management, vol. 36, no. 1, pp. 4-9.

Shipley, D. (1984). 'Selection and Motivation of Distribution Intermediaries', Industrial Marketing Management, no. 13 (October), pp. 249-256.

Skinner, S. and Guiltinan, J. (1985), 'Perceptions of Channel Control,' Journal of Retailing, no. 61 (Winter), pp. 65-88.

Stem, L., El-Ansary, A. and Coughlan, A. (1996). Marketing Channels (5th edition). Upper Saddle Creek, NJ: Prentice-Hall Publishers.

Webster, F.E. (1991). 'The Role of the Industrial Distributor in Marketing Strategy', Journal of Marketing, vol. 40, no. 1, pp. 10-16.

Zeithaml, V. A. (1988). 'Consumer Perceptions of Price, Quality, and Value: A Means-End Model and Synthesis of Evidence', Journal of Marketing, no.52 (July), pp. 2-22. 


\section{Bio-note}

Joseph Edewor Agbadudu (PhD) is a Senior Lecturer in the Department of Business Administration, University of Benin, Benin City, Nigeria. His areas of interest are operations management, business statistics and entrepreneurship.

Simon Ayo Adekunle is a First Class Honours graduate of Business Administration in the Department of Business Administration, University of Benin, Benin City, Nigeria. He is a Lecturer and $\mathrm{PhD}$ candidate in the Department. His research interest and areas of specialization are operations management, quantitative analysis, marketing and business research. He is a certified data analyst in Microsoft Excel, Statistical Packages for Social Sciences (SPSS), Econometric Views (EViews), among others. 